\section{Livskvalitet i livets siste fase}

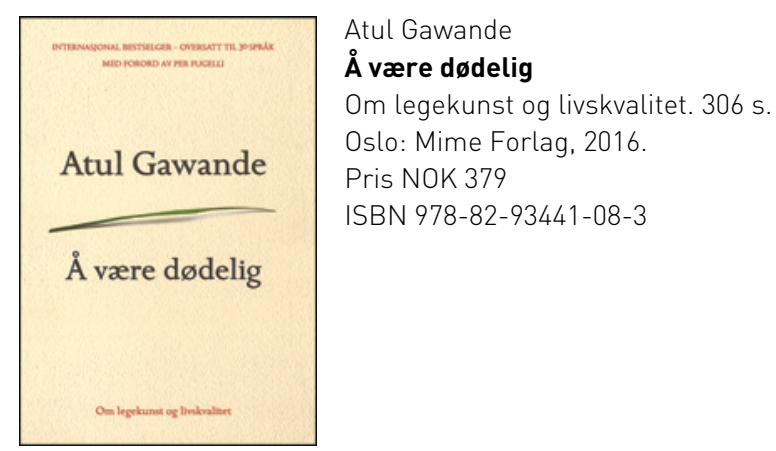

Den indisk-amerikanske kirurgen Atul Gawandes bok om livets siste fase er nå blitt utgitt på norsk. Jeg tok fatt på lesingen med fordommer: Amerikanerne er kjent som verdensmestre i kostbar og hodeløs overbehandling ved livets slutt - har de noe å lære oss nordmenn? Men Gawande viser seg raskt som en klok guide i dette landskapet.

Denne teksten om livets siste fase favner bredt. Forfatteren formidler fagkunnskap om aldring og viser hvordan demografiske og økonomiske endringer har endret måten eldre lever på. Økonomisk frihet gir generasjonene frihet til å velge å bo hver for seg. Dette skaper utfordringer når de eldres funksjonsnivå faller, og de mister evnen til selvhjulpenhet.

Hovedbudskapet er for det første at helsetjenesten bedriver utstrakt over- og underbehandling ved livets slutt: overbehandling fordi vi overvurderer potensialet i livsforlengende behandling og undervurderer bivirkningene, og underbehandling fordi vi glemmer å sette inn palliativ behandling tidlig nok. Dette er velkjente problemer også fra Norge. Problemet settes på spissen i USA fordi visse palliativtjenester der forutsetter at du har frasagt deg livsforlengende behandling.

Gawande blir en spesielt sympatisk forteller fordi han innrømmer at han mange ganger selv har bommet kraftig. Han beskriver hvordan han har vært unnvikende og skjønnmalende i samtaler med pasienter om deres prognose. Han har anbefalt intervensjoner med tvilsom nytte, fordi alternativet, den ærlige samtalen om døden og «nokpunktet», er så mye mer krevende.

Det andre hovedbudskapet er at vi må bli dyktigere til å gi de eldre det de selv ønsker, slik at de kan få den beste livskvaliteten. Og hva ønsker de eldre? Fremfor alt ønsker de mening, selvbestemmelse og frihet. Dette kolliderer med de pårørendes og institusjonenes behov for trygghet og sikkerhet. Vi bør gå bort fra den livshemmende ideen om at de gamles sikkerhet trumfer alt, til fordel for livskvalitet her og nå.

Gawandes budskap er viktig. Samtidig må vi ikke skape en ny myte om hva eldre vil. Vil ikke mange ha det ypperste av medisinsk behandling hvis den er tilpasset den gamle kropps tåleevne?

Denne lettleste boken drives frem av en rekke illustrerende historier. Noen uttrykk fra helsesektoren er oversatt feil, slik som «omsorgsbehandling» for «palliative care», og den amerikanske helsetjenesten er organisert ulikt fra den norske. Av disse grunnene ville det være flott med en helnorsk bok om de samme spørsmålene. Men norske lesere, både lekfolk og helsepersonell, vil finne at denne utgivelsen gir kunnskap og nye perspektiver.

\section{For de spesielt interesserte}

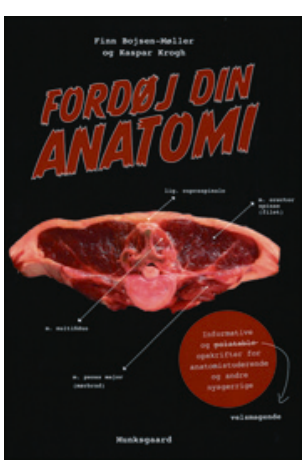

Finn Bojsen-Møller, Kaspar Krogh

Fordøj din anatomi

128 s, ill. København: Munksgaard, 2017.

Pris DKK 195

ISBN 978-87-628-1744-9

Det er en økende bevissthet rundt hva vi spiser. Kjøttfrie mandager er blitt forsøkt innført flere steder, og høyt forbruk av rødt kjøtt er stadig et diskusjonstema. Men det er neppe denne trenden forfatterne ønsker å bygge opp under.

På forsiden er det et bilde av en lammekotelett der ulike anatomiske strukturer er angitt. Dette bildet illustrerer essensen av innholdet: en anatomisk tilnærming til de forskjellige delene av dyret vi spiser.

Boken er delt inn i to hoveddeler. Den første delen omtaler varmefysikk, smaksfysiologi, kjemi, hygiene, forskjellige slakteteknikker og utskjæringer av kjøttet. I fysikkdelen illustreres varmetransport og oppvarming av kjøtt med Fouriers ligning, Stefan-Boltzmanns lov og formelen for konveksjon. I kjemidelen blir det gitt en forklaring på hvorfor stekeskorpe er godt, hvordan kollagenet omdannes til gelatin, og hvorfor man ikke må skjære gjennom fascien når man ruter ribbe før den saltes.

Den øvrige delen vies til 22 oppskrifter, ispedd kapitler om kugalskap og forklaring på hvorfor pølser alltid sprekker på langs og ikke på tvers. Til hver oppskrift er det en grundig anatomisk forklaring av hovedingrediensen, være seg hjerte, nyre, testikkel, brissel, lever, tunge eller lammebog. Fugl og fisk omtales over ti sider, der de vanligste fallgruvene man må unngå, er beskrevet. Oppskriftene er lette å følge og krever ikke spesielle forkunnskaper eller utstyr, dog er jeg usikker på hvor mange som umiddelbart kommer til å lage leverkarbonader. Oppskriftene er på ingen måte innovative, og mye av søkelyset er på strukturell og funksjonell beskrivelse av råvaren.

Forfatterne, den ene veterinær, den andre lege, har klart å komprimere mye kunnskap på 128 sider. Deres intensjon er å spre dybdekunnskap om animalske råvarer og hva som skjer under tilberedning av disse. I så måte er boken interessant for den nysgjerrige og den med interesse for kulinariske virkningsmekanismer, men min personlige erfaring er at flertallet i mindre grad er opptatt av dette.

Boken er ryddig oppsatt, men layout er litt rotete med tekstbokser limt overlappende på bilder.

Jeg anbefaler boken til alle som er nysgjerrige på kjøttmat og matlaging utover det kun å bli mett. Det er ikke en bok for de som primært ønsker seg en oppskriftsbok om eksperimentell, kortreist nordisk vegetarmat.

\section{Marius Lund-Iversen}

Lege, spesialist i patologi Oslo universitetssykehus 